\author{
Marek GOSZTYŁA ${ }^{1}$ \\ Bogdan MOTYL ${ }^{2}$
}

\title{
ZABYTKI TECHNIKI MIASTA PRZEMYŚLA Z PRZELOMU XIX/XX WIEKU
}

\begin{abstract}
W drugiej połowie XIX i na początku XX w. w rozwoju przestrzennym Przemyśla znaczącą rolę odegrały trzy główne czynniki: budowa umocnień twierdzy wokół Przemyśla i towarzysząca jej budowa całego systemu koszar i zaplecza logistycznego dla twierdzy w obrębie miasta [1, s. 10], budowa w 1859 r. linii kolejowej łączącej Przemyśl z Krakowem, Wiedniem oraz Lwowem i linii kolejowej łączącej Przemyśl przez przełęcz Łupkowską z Węgrami w 1872 r. [1, s. 16] Trzecim czynnikiem było uchwalenie 23 XII 1891 r. regulacji ulic Przemyśla, która dotyczyła niemal całego miasta [2]. Była to ogólnoeuropejska tendencja związana z okresem nazywanym również drugą rewolucją przemysłową. W Przemyślu wyznaczono nową sieć komunikacyjną drogową i kolejową, nowoczesne na ówczesne standardy place targowe, wybudowano wiadukty drogowe, infrastrukturę techniczną tj. stację i sieć wodociągową, elektrownię i sieci kanalizacyjne. Budowle inżynierskie wybudowane w tamtym okresie służyły miastu aż do końca XX wieku, a inwestycje drogowe, architektoniczne po pracach modernizacyjnych i konserwatorskich włączone do współczesnych miejskich funkcji są świadkami rozwoju przestrzennego ośrodka. Zabytkowa infrastruktura stanowi dodatkową wartość kulturową organizmu miejskiego.
\end{abstract}

Słowa kluczowe: dziedzictwo kulturowe, budowle inżynieryjne, zespół staromiejski, regulacje miasta, detal architektoniczny

\section{Wprowadzenie}

Zmiany w urbanistce miast w XIX w. i na przełomie XIX/XX w. niosły ze sobą szereg inwestycji przemysłowo-inżynieryjnych. Miasto Przemyśl, przeznaczone w połowie XIX wieku, przez Austro-Węgry na miasto twierdzę, uzyskało nowy status ośrodka miejskiego. Rozwój miasta związany z nowymi inwestycjami o funkcji obronnej i zapleczem logistycznym, był czynnikiem determinującym w zakresie zmian kształtu struktur przestrzennych Przemyśla. Odnotowa-

\footnotetext{
${ }^{1}$ Autor do korespondencji / corresponding author: Marek Gosztyła, Politechnika Rzeszowska, 35-959 Rzeszów, al. Powstańców Warszawy 12, tel. + 4817865 1939, gosztyla@prz.edu.pl

2 Bogdan Motyl, motyl.bogdan@gmail.com
} 
ny wyż demograficzny, przyczynił się również do realizacji nowych projektów $\mathrm{z}$ dziedziny infrastruktury miejskiej.

Plan regulacji wykonano w wyniku nakazu administracyjnego, jak to określono we wstępie uchwały o regulacji miasta Przemyśla na prośbę władz wojskowych i Namiestnictwa [2]. Jego realizację ukończono w latach 1900-1914 r. [3, s. 23]. Jedną, z pierwszych ulic, którą poddano planowanej regulacji, była ulica Juliusza Słowackiego (zwana wcześniej Dobromilską lub Nehrebecką) (rys. 1). Wytyczona została jeszcze za Kazimierza Wielkiego jako droga biegnąca poza murami miasta i omijając bagno [4, s. 57], prowadziła wzdłuż murów miejskich do żupy solskiej [5, s. 15]. Po częściowym zburzeniu murów miejskich w XVIII w. droga ta uległa stopniowej przebudowie i przekształciła się w jedną z najważniejszych ulic miasta. W latach 1830 - 1850 wykonano na niej nawierzchnię utwardzoną tzw. bitą. Związane to było z ulokowaniem na jej końcu około 1855 roku nowego cmentarza miejskiego rzymskokatolickiego i żydowskiego [6].

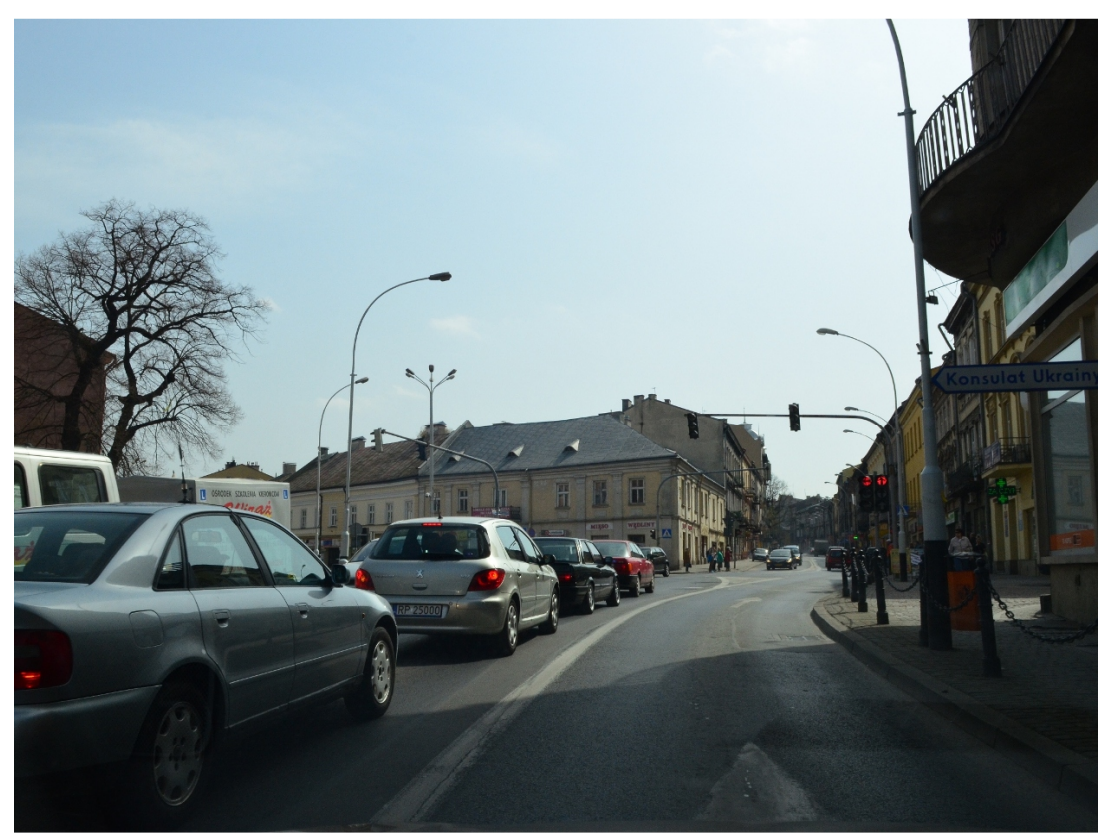

Rys. 1. Wnętrze ulicy Słowackiego (dawna ulica Dobromilska), fot. R. Oleszek

Fig. 1. Inside of the Słowackiego street (former Dobromilska street), photo. R. Oleszek

Wcześniej w 1887 r. oddano do użytku kompleks Szpitala Wojskowego składający się z 18 budynków i kaplicy [7] oraz w 1898 r. koszary 10 pułku piechoty składające się z 13 budynków [7]. Wkrótce po wybudowaniu koszar powstał w 1894 nowy reprezentacyjny gmach Gimnazjum im. J. Słowackiego 
[8]. W roku 1894 ulicę Słowackiego poddano pracom modernizacyjnym, które nadzorował drogomistrz miejski pan Krzyżewski [9, s. 3].

Dzięki zachowanym planom regulacji można prześledzić z jakimi trudnościami spotykali się ówcześni planiści miejscy [10]. Według sporządzonych planów zmodernizowano profil poprzeczny ulicy przez jego ujednolicenie, w miejscach przewężeń ulicę poszerzono i miała ona jednolitą szerokość na całym jej przebiegu wynoszącą średnio $16 \mathrm{~m}$, oraz stały spadek na całej długości wynoszący $37,07 \mathrm{~m}$ na $1000[11, \mathrm{~s} .5]$.

$\mathrm{Z}$ początkiem XX w. powstał przy tej ulicy szereg reprezentacyjnych kamienic i budynków mieszkalnych, między innymi kamienica nr 13 zbudowana w 1912 r. przez znanego przemyskiego właściciela domów czynszowych Juliusza Kleina [12]. Zbudował on kamienicę o wysokim standardzie wyposażenia mieszkań i bogatej ornamentyce fasady, która przeznaczona była dla ludzi o wysokim statusie majątkowym.

W 1910 r. znani przemyscy przedsiębiorcy Joachim Klagsbal i Majer Honigwachs zbudowali dom mieszkalny pod $\mathrm{nr} 61$, o założeniu rezydencjalnym, $\mathrm{z}$ budynkiem gospodarczym i stajnią w podwórzu [13]. W tym samym roku rozpoczęto budowę monumentalnego gmachu Stowarzyszenia Synagogi Przemyskiej. Obiekt ten zaprojektowany przez Stanisława Majerskiego ukończono w 1918 r. [14].

Wybudowane w drugiej połowie XIX wieku torowiska odcinały naturalne połączenia drogowe i trzeba było w miarę rozwoju ruchu na drogach budować wiadukty i tunele. Ponadto torowiska utrudniały rozbudowę infrastruktury miejskiej w postaci wodociągów i kanalizacji [15, s. 9]. Podobnie było z budownictwem koszarowym. Te inwestycje, które przed pierwszą wojną światową napędzały koniunkturę miasta Przemyśla, po wojnie w znaczny sposób hamowały i ograniczały jego rozwój, gdyż zajmowały przeważnie najlepsze tereny budowlane.

W artykule starano się przedstawić obiekty, które w rozwoju przestrzennym miasta zaznaczyły się jako ogniwa, tzw. katalizy, wokół których kształtował się rozwój struktur miejskich. Budynki i budowle o charakterystycznej architekturze i programach funkcjonalnych wybudowane w XIX wieku i na początku XX wieku, które do dziś służą mieszkańcom miasta, na trwałe wpisały się w jego kulturowy krajobraz.

\section{Budowle inżynieryjne jako czynnik rozwoju układu przestrzennego miasta}

Niewątpliwie najbardziej rozpoznawalnym jest tu wiadukt nad torami biegnący w ciągu ulicy Kamienny Most (rys. 2). 


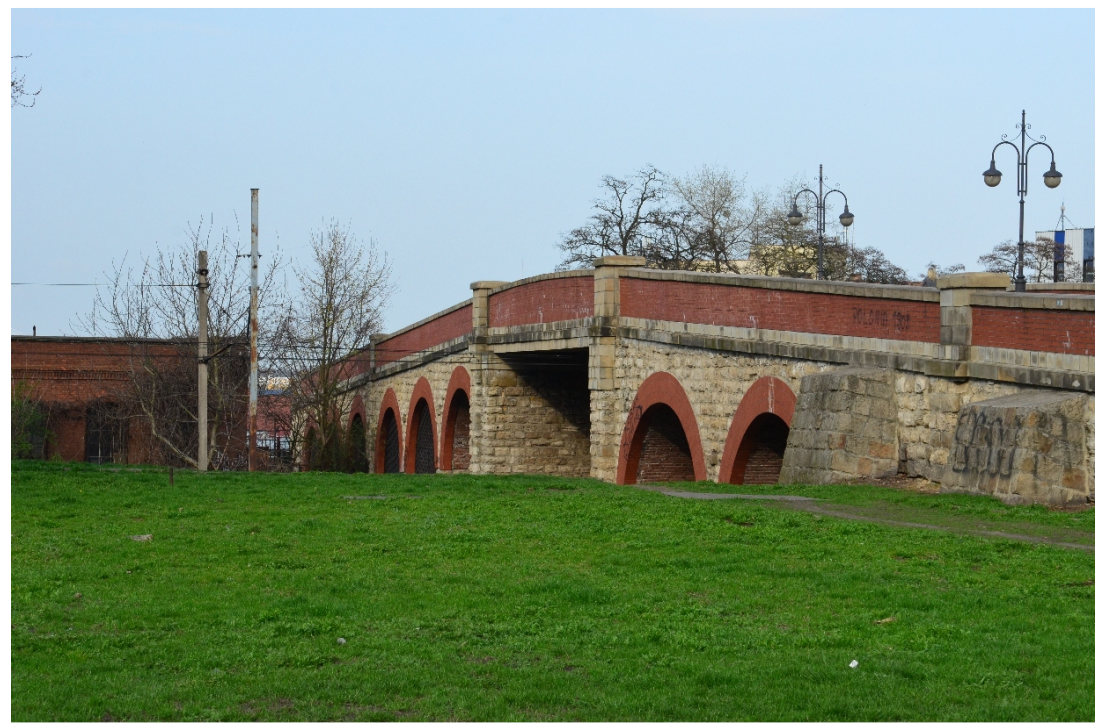

Rys. 2. Wiadukt tzw. kamienny most, fot. R. Oleszek

Fig. 2. Viaduct called stone bridge, photo. R. Oleszek

Dokładnej daty jego powstania nie znamy, ale zapewne wybudowano go po uchwaleniu planu regulacji ulic Przemyśla w 1891 r. ${ }^{3}$ [16, s. 122-123], w którym przyjęto budowę ul. Przejazd (dzisiejszy Kamienny Most) [2]. Istnieje pogląd, że most ten mógł powstać już w trakcie budowy kolei Kraków - Lwów około 1870 r., lecz miał on wtedy odmienną konstrukcję, i w miejsce dzisiaj istniejącego przęsła płaskiego posiadał dwa sklepienia nad torami oparte na filarze, które $\mathrm{w}$ trakcie remontu usunięto, a sklepienia zastąpiono przęsłem dźwigarowym. [17, s. 12-13] Z dostępnych dokumentów wynika, że miał on być wybudowany kosztem inwestycji Kolei Karola - Ludwika [2, s. 3 i dalsze] i funkcjonował już w 1896 r. Jego rysunek widoczny jest na projekcie dekoracji z okazji przyjazdu Cesarza Franciszka Józefa do Przemyśla i ma prosty dźwigar nad torowiskiem [18]. Most nad torowiskiem po przebudowie posiadał dźwigary o konstrukcji stalowej. Obecnie dźwigary są żelbetowe i opierają się na przyczółkach, do których biegną podjazdy, które wznoszą się z poziomów łączących most i ulice, i oparte są na kolebkowo sklepionych arkadach. Podstawę mostu stanowią wysokie na $11 \mathrm{~m}$ filary, które w części środkowej podtrzymują obecnie żelbetowy prosty most o rozpiętości $11,9 \mathrm{~m}$ i szerokości $14 \mathrm{~m}$, stanowiące jednocześnie oparcie dla wezgłowi pierwszych łuków zjazdu. Zjazd ten od strony północnej

\footnotetext{
${ }^{3}$ Autorzy we wcześniejszej publikacji pt „Zabytki architektury przemysłowej Przemyśla” zamieszczonej w wydawnictwie Archeologia Przemysłowa w Polsce, t. 3, s. 122-123, podali za kartą białą sygn. A-705/709 ze zbiorów WUOZ z siedzibą w Przemyślu rok 1917 jako datę budowy Kamiennego Mostu, niniejszym artykułem tą omyłkę skorygowano.
} 
zbudowany jest z sześciu łuków kamiennych opartych na filarach. Łuki te mają w strzałce połowę swojej średnicy wynoszącej $5 \mathrm{~m}$ i długość $14 \mathrm{~m}$. W każdym przęśle występują po trzy łuki, które wsparte na różnej wysokości filarów tworzą efekt obniżenia architrawu z $10 \mathrm{~m}$ do $3,6 \mathrm{~m}$ i zejścia jezdni łagodnym skrętem w kierunku wschodnim do poziomu ul. Czarnieckiego [19]. Od strony południowej różnica poziomu terenu była mniejsza, stąd zbudowano tylko dwa łuki o strzałce również stanowiącej połowę średnicy łuku wynoszącej $6 \mathrm{~m}$. Za łukami od strony zachodniej zastosowano dwie przypory, obecnie zasypane ziemią i widać ich wierzchołki. Filary mostu zbudowano z kamienia oblicowanego ciosami z piaskowca, koleby łuków wykonano z cegły, a archiwolty zaznaczono cegłą klinkierową. Na filarach mostu i filarach rozdzielających grupy łuków w części północnej po obu stronach umieszczono lizeny obłożone ciosami kamiennymi takimi jak reszta budowli. W części górnej filary i lizeny obecnie obłożone są płytami z piaskowca, jest to efekt remontu mostu w 2000-2002 r. Korpusy zjazdów powyżej archiwolt obłożone są ciosami kamiennymi tak samo jak filary i zakończone gzymsami obłożonymi płytami również z piaskowca. Po wiadukcie biegnie brukowana droga z chodnikami zabezpieczonymi pełną balustradą obłożoną klinkierową cegłą. Balustrady zakończone są parapetem z piaskowca o łukowatym wierzchu wysuniętym poza obręb balustrady. Balustrada podzielona jest filarkami zakończonymi wystającymi poza ich obręb płaskimi fazowanymi daszkami z piaskowca, przebiegającymi w osiach lizen filarów. W części głównej wiaduktu nad torami wysokość balustrady wynosi $1,80 \mathrm{~m}$, a w części pozostałej 1,20 m [19].

Wiadukt ten komunikował miasto z nowo powstałą targowicą zwaną Placem Nowym. Placem handlowym do XIX wieku był w mieście rynek, i tu koncentrowało się życie miasta oraz wzrastało jego bogactwo. W miarę rozwoju miasta stary rynek był za ciasny, zwłaszcza do handlu płodami rolnymi na dużą skale. Stąd wyniknęła potrzeba utworzenia nowej, dużej miejskiej targowicy. Jednym z dogodnych miejsc, gdzie można było ulokować plac handlowy, były tereny leżące między torowiskiem kolei Karola - Ludwika a Sanem. Miejsce to zapewniało nieskrępowany dostęp do rzeki i do kolei oraz nie powodowało zakłóceń i kolizji komunikacyjnych w mieście $\mathrm{w}$ razie pędzenia bydła i przewozu płodów rolnych.

3 sierpnia 1893r. Rada Miejska uchwaliła budowę na targowicy: stajni spędowej, urządzenie placu obserwacyjnego i rewizyjnego oraz budowę komisariatu targowego. W wyniku przetargu budowę zlecono firmie pana Pileckiego. [20, s. 2] Na targowicy do tego czasu istniał szereg drewnianych obiektów, które nie zachowały się do dnia dzisiejszego. Zachował się natomiast, i pomimo utraty przez późniejsze adaptacje pewnych cech architektonicznych, nadal pełni swoją funkcję budynek byłego komisariatu targowego wraz ze stajnią. Jest to parterowy budynek wieloskrzydłowy założony na planie litery $\mathrm{H} \mathrm{z}$ użytkowym poddaszem i korpusem głównym na linii północ - południe. Kalenica dachu w części centralnej przebiega prostopadle do kalenic dachów skrzydeł. Obecnie dach 
posiada pokrycie z blachy przetłaczanej. Połacie dolne dachu korpusu znajdują się poniżej połaci dachu skrzydel. Istotne cechy architektoniczne obiektu zachowały się od strony zachodniej. Attyka w skrzydle południowym od strony zachodniej posiada zdobienie $\mathrm{w}$ postaci schodkowego ornamentu zwieńczonego gzymsem okutym blachą. Po bokach kończy się fajermurami, całość wsparta jest na gzymsie wieńczącym dolną kondygnację. W szczycie znajdują się dwa wąskie, podłużne, łukowato zakończone okna bez obramowań, z łukowymi obdasznicami, z zaznaczonymi klińcami i prostymi parapetami. Poniżej występuje gzyms prosty okuty blachą i ściana parteru z dwoma współczesnymi oknami z zaznaczeniem śladów po obdasznicach okien pierwotnych. Na ścianie nad oknami przebiega płaski gzyms. Elewacja między skrzydłami jest dziesięcioosiowa, z wnękami zwieńczonymi łukami odcinkowymi i obdasznicami z klińcem. Obecnie dwa otwory są zupełnie zamurowane, w czterech znacznie zmniejszono światło, dwa wydają się pozostawać oryginalne, a dwa adoptowano na drzwi. W elewacji wybito dodatkowe okno, zakłócając historyczny podział.

Północna ściana skrzydła południowego jest całkowicie przebudowana, posiada współczesny otwór drzwiowy i okno, na ścianie zaznaczona jest obdasznica po wcześniejszym oknie.

Natomiast przeciwległa południowa ściana skrzydła północnego posiada trzy okna współczesne, które znajdują się w pierwotnych otworach u góry zwieńczonych obdasznicami z klińcem, podobnie jak znajdujące się tam w miejsce czwartego okna, drzwi.

Ściana zachodnia tego skrzydła posiada attykę podobną jak pozostałe z tym, że pierwotne okna w szczycie, zastąpiono jednym podwójnym współczesnym oknem. Poniżej attyki, wyprofilowany gzyms, kończy ścianę z trzema oknami, w tym środkowe zamurowane (blenda). Współczesne okna zamontowano w pierwotnych otworach, nad którymi znajdują się obdasznice z klińcami. Ściana obramowana jest boniowanymi narożnikami i boniowanym cokołem z gzymsem. Ściana północna skrzydła całkowicie utraciła pierwotny wystrój. Elewacja wschodnia skrzydła oprócz zdobnej attyki i gzymsów nie zachowała pierwotnych otworów i zdobień. Ściana poniżej gzymsu obramowana jest boniowanymi narożnikami i cokołem. Ściana wschodnia korpusu po adaptacjach posiada trzy duże podwójne drzwi z nadświetlami. Elewacja wschodnia skrzydła południowego posiada attykę, w szczycie oryginalne otwory okienne, takie jak ściana zachodnia. Podobnie również wygląda ściana poniżej attyki. Elewacja południowa pierwotnie posiadała osiem otworów okiennych. Cztery z nich znajdowały się na zaznaczonym ryzalicie, a po dwa na bokach elewacji. Okna w historycznym obiekcie miały jednorodne kształty. Budynek wzniesiony do obsługi targowicy nadal służy celom handlowym i znajdują się tam sklepy i hurtownie.

W celu ułatwienia transportu i komunikacji z częścią miasta za Sanem poniżej targowicy (rys. 3) wybudowano drewniany most o dziesięciu przęsłach, długości 205,60 m i szerokości $8 \mathrm{~m}$. 


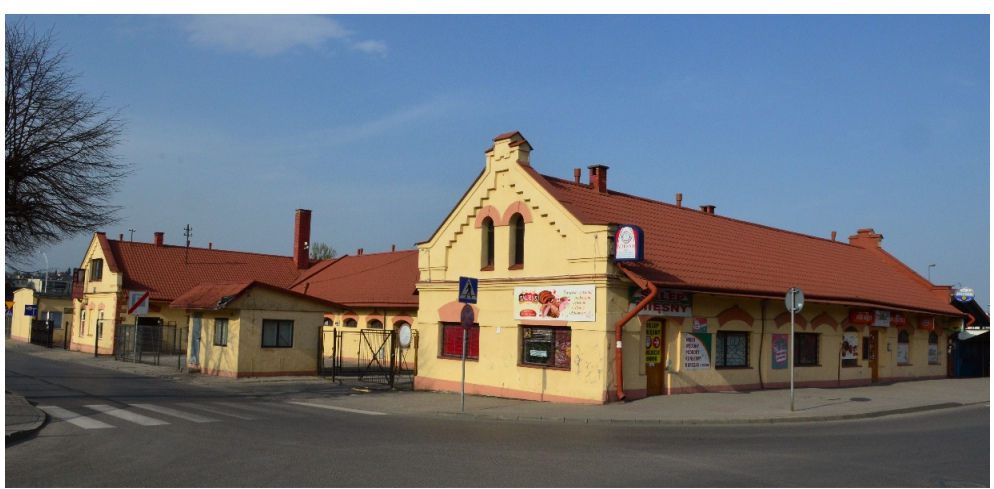

Rys. 3. Były budynek targowicy, fot. R. Oleszek

Fig. 3. Former building of targowica, photo. R. Oleszek

Jego wykonawcą była firma G. Ziębicki wyłoniona w przetargu 26 lutego 1892 r. [21]. Most łączył ulicę Strycharską z ulicą Borelowskiego w dzielnicy Zasanie. Obecnie w jego miejscu stoi most współczesny.

$\mathrm{Z}$ chwilą budowy kolei Łupkowskiej i połączenia jej z koleją z Wiednia do Lwowa torowisko przecięło drogę Przemyśl - Lwów, zaszła wtedy potrzeba budowy wiaduktu (rys. 4). Zbudowano go w 1897 r. równolegle do drogi od strony południowej tworząc objazd [3, s. 40]. Był to wiadukt o konstrukcji stalowej kratownicowej nitowanej o jezdni dolnej. Forma projektu kontrastowała [22, s. 189] z sąsiadującą zabudową. Negatywną opinię na jego temat wyraził R.K. Rosłoński pisząc, że wiadukt szpeci krajobraz i nadaje się do jakiejś podgórskiej wioski [15, s. 9].

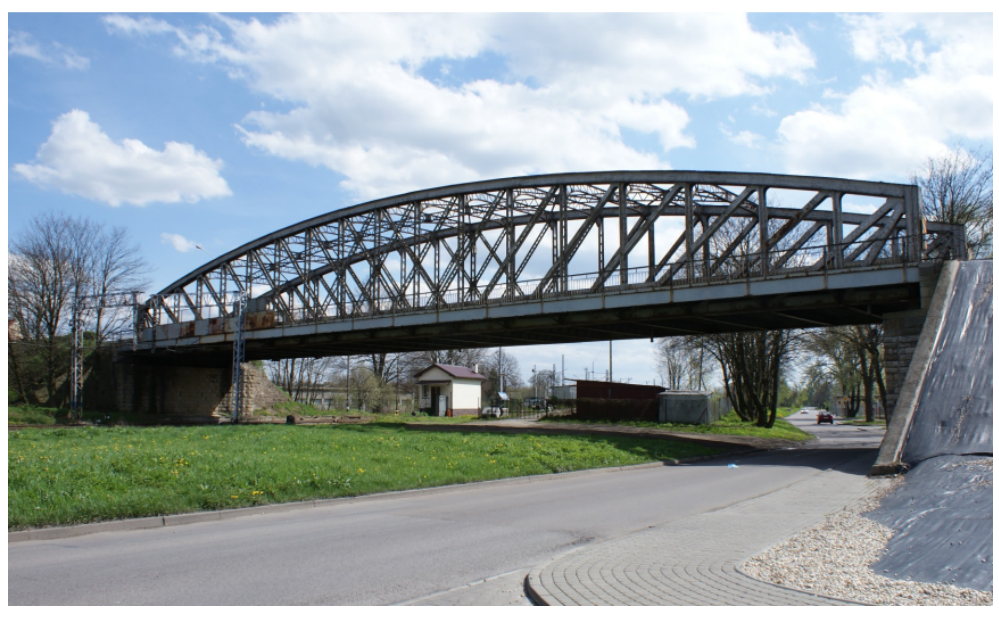

Rys. 4. Wiadukt, ulica T. Zana, fot. B. Motyl

Fig. 4. Viaduct, T. Zana street, photo. B. Motyl 
Most ma już ponad sto lat i na trwałe wrósł w kulturowy krajobraz Przemyśla. Jego charakterystyczna sylwetka i konstrukcja jest typowa dla obiektów budowanych pod koniec XIX w. Wiadukt posiada jedno przęsło o konstrukcji kratownicowej, nitowane ze stalowych kształtowników o jezdni dolnej [23, s. 2]. Jezdnia składa się z stalowego rusztu, na którym ułożono obecnie żelbetonowe płyty i asfalt. Dźwigary główne tworzą kratownice, które u góry połączone są poprzecznicami i dwoma górnymi pasami wzdłużnymi o kształcie odcinka łuku, a pomiędzy nimi biegnie beleczka - kratownica stabilizująca. Słupy zwiatrowane są dwustronnie zastrzałami w kierunku od jezdni do górnych pasów dźwigara po przekątnej w kierunku lewym i prawym od końca dźwigarów. W przypadku czterech środkowych par słupów występuje zwiatrowanie krzyżulcowe. Słupy i zwiatrowania mają konstrukcje ażurową. W łączeniach kształtowników i blach użyto techniki nitowania nitami stalowymi, węzły na łączeniach są wzmocnione przez dodanie dodatkowych elementów stalowych. Główne pasy nośne dźwigarów na poziomie jezdni wykonane są o przekroju podwójnego teownika, pasy górne dźwigarów o kształcie odcinka łuku, w przekroju mają kształt ceownika. Wzdłuż jezdni po zewnętrznych stronach przęsła na stalowych wspornikach umieszczony są ciągi piesze zabezpieczone balustradą. Przęsło wiaduktu wsparte jest na dwóch filarach, obłożonych ciosami z piaskowca. Na poziom jezdni wiaduktu prowadzą podjazdy wykonane w postaci ziemnych nasypów oskarpowanych ciosami kamiennymi przy filarach. Podjazdy te skręcają w stronę północną i utworzono z nich ul. Zana dochodzącą do ulicy Mickiewicza od strony zachodniej i skrzyżowania z ulicą Zielińskiego od strony wschodniej.

Jak już wspomniano przęsło wiaduktu ma konstrukcję stalową nitowaną, podobną konstrukcję posiadał główny most na Sanie zbudowany w 1895r na miejsce poprzedniego drewnianego. Był to jeden z dwóch mostów drogowych łączących obie części miasta. Most posiadał trzy przęsła, główne przęsło przypominało kształtem przęsło wiaduktu nad torami kolejowymi. W przęśle środkowym pary słupów nośnych posiadały zwiatrowania w postaci układu krzyżulcowego. Przęsło było posadowione na dwóch kamiennych podporach $\mathrm{z}$ piaskowca [24, s. 7]. Do przęsła głównego prowadziły z każdej strony dwa przęsła dojazdowe o kratownicy posiadającej u góry proste belki wzdłużne. Pary słupów górą połączono łukowymi tężnikami. Słupy dodatkowo zwiatrowane były stalowymi ściągami na krzyż. Przęsła dojazdowe wspierały się z jednej strony na filarach przęsła głównego a $\mathrm{z}$ drugiej strony na przyczółkach brzegowych. Ostatnia para słupów przęseł dojazdowych zwieńczona była stalowymi stojakami zaopatrzonymi w cztery pary izolatorów na wieszakach służących do mocowania przewodów elektrycznych. Na końcach przęseł dojazdowych centralnie wisiały lampy oświetleniowe. Przęsło dojazdowe od strony rynku zaopatrzone było w dwa pomosty rewizyjne biegnące pod przęsłem, do których prowadziła drabinka z prawej strony.

Na filarze znajdował się wodowskaz. Most wspierały dwa filary o konstrukcji kamiennej na rzucie spłaszczonej elipsy o zwężającym się ku górze 
przekroju zakończonym gzymsem [25]. Powyżej gzymsu znajdował się podłużny fundament wspierający kotwienia mostu. $Z$ obu stron przęseł na stalowych wspornikach znajdowały się pomosty z chodnikami dla pieszych [26].

Obecnie do dziś pozostały z tego mostu tylko filary na których spoczywa most współczesny [24, s. 7].

\section{Rozwiązania infrastruktury miejskiej zmieniające standard dzielnic}

Mówiąc o rozwoju przestrzennym miasta Przemyśla należy wspomnieć również o infrastrukturze, która jest być może mniej widoczna, ale stanowi istotny element miasta i jego rozwoju. Miasto to przecież, nie tylko budynki i drogi, ale także wspólnota ludzi, która realizuje potrzeby bytowe swoich mieszkańców. Ewoluująca cywilizacja potrzebowała bezpieczeństwa i warunków do rozwoju, stąd budowa systemów obronnych, domów i oświetlenia ulic, miejskich studni, młynów, browarów, rzeźni, placów handlowych, szkół i szpitali. W wyniku rozwoju przestrzennego organizm miejski Przemyśla mógł zapewnić swoim mieszkańcom potrzeby bytowe do połowy XIX w. Gdy zaczęła się tak zwana druga rewolucja przemysłowa, w związku ze wzrostem liczby ludności, potrzeby były coraz większe, a wybudowanie linii kolejowych łączących Przemyśl z Europą spowodowało istotny rozwój ośrodka. Trzeba pamiętać, że ówczesna monarchia austro-węgierska rozciągała się od Włoch po granice z Rosją. Pojawiły się nowe wynalazki min. za zakresu elektryczności. Przemyśl był w tym względzie pionierem i jako pierwsze miasto w Galicji wprowadził elektryczne oświetlenie ulic. Wybudowano w 1896r. elektrownie i siec oświetleniową, która zastąpiła dotychczasowe oświetlenie naftowe.

Była to jak na owe czasy już przestarzała elektrownia, posiadająca moc $165 \mathrm{KW}$ wytwarzaną przez trzy maszyny parowe firmy Ringhoffer i prądnice prądu stałego firmy Siemens-Halske [27, s. 35], dlatego też, aby sprostać wzrastającemu zapotrzebowaniu na energię elektryczną, wkrótce wybudowano nową elektrownię obok targowicy. Nowa elektrownia podjęła pracę w 1910 r. Wyposażona była $\mathrm{w}$ dwie maszyny parowe sprzężone bezpośrednio z prądnicami o mocy $200 \mathrm{KW}$ każda [27], mimo tego, nowa elektrownia nie była zdolna pokryć nadal wzrastającego zapotrzebowania na prąd. W związku z tym w 1913 r. swoją elektrownię uruchomiła kolej [27]. W 1918 r. elektrownia zasilała oświetlenie miejskie składające się z 14 lamp $500 \mathrm{~W}, 3$ lamp po $150 \mathrm{~W}$ i 200 lamp po $75 \mathrm{~W}$. Ponadto przyłączonych było 2210 odbiorców prądu, którzy używali 18000 szt. lamp różnej mocy. Pobór prądu rozliczano ryczałtem bądź za pomocą zegarów systemu „Aubert” [28, s. 7]. Spory wzrost zapotrzebowania na energię elektryczną spowodował, że w 1918 r. uruchomiono trzeci nowy zespół maszynowy o mocy $400 \mathrm{KW}$. Ten trzeci zespół składał się z kotła parowego, turbiny parowej i generatora [28, s. 4]. 
Ponadto zlikwidowano zespół akumulatorów, który stabilizował prace sieci podczas przeciążeń, zastępując go agregatami wyrównawczymi. Siec stanowiły przewody prowadzone na drewnianych słupach i żelaznych wspornikach przykręconych do ścian kamienic [28, s. 5], które były podłączone do siedmiu rozdzielni znajdujących się w stalowych kioskach. Prąd do rozdzielni z elektrowni doprowadzano podziemnymi kablami [27, s. 45]. Zmiana sposobu zasilania z prądu stałego na prąd zmienny spowodowała, że elektrownie zlikwidowano. Pozostał kompleks charakterystycznych budynków z kominem, rozebranym po 2005r. Budynki te służyły i nadal służą przemyskiej energetyce do celów administracyjnych.

Kolejnym ważnym elementem infrastruktury miasta Przemyśla, który rozrastał się wraz z przestrzennym rozwojem miasta, był system zaopatrzenia w wodę i kanalizacja.

W 1917 r. powstał projekt Kanalizacji Królewskiego Wolnego Miasta Przemyśla sporządzony przez dr. Romualda K. Rosłońskiego [15, s. 1]. Projekt ten unowocześniał dotychczas istniejącą kanalizację wybudowaną w przeciągu wieków podczas rozwoju miasta. Początek kanalizacji w Przemyślu dała budowa kanału o długości $800 \mathrm{~m} \mathrm{z}$ zamku i kapituły rzymskokatolickiej przy katedrze do Sanu. Następnie wybudowano kanał z klasztoru Karmelitów o długości 700 m [15, s. 7], trzeci kanał biegł z klasztoru Reformatów i miał długość 250 m, czwarty o długości 130 m łączył klasztor Dominikanów z rzeką, a piąty długi na $150 \mathrm{~m}$ klasztor żeński Dominikanek. Kanały te powstały prawdopodobnie w siedemnastym i osiemnastym wieku podczas remontu zamku i katedry oraz budowy w mieście zespołów klasztornych. Stopniowo do tych kanałów dołączano kanały i przykanaliki z posesji miejskich, tak że w 1917 r. długość kanałów w śródmieściu wyniosła około $4 \mathrm{~km}[15, \mathrm{~s} .8]$. Kanały główne miały przekrój prostokątny o wysokości $1 \mathrm{~m}-1,65 \mathrm{~m}$ i szerokości $0,8-1,10 \mathrm{~m}$. Wybudowano je z nieregularnego kamienia na zaprawie wapiennej i przesklepiono [15, s. 7]. Poza śródmieściem do 1917 r. kanały budowano na koszt inwestorów i miały one różną długość i różne przekroje. Osobną kanalizację od czasów rozpoczęcia budowy obiektów zaplecza Twierdzy Przemyśl wybudowało wojsko.

Projektanci wojskowi budowali kanalizacje bez uzgadniania $\mathrm{z}$ władzami miasta stąd dochodziło na tym tle do licznych konfliktów. [15, s. 10] Kres tej samowoli położył początek wojny i wprowadzenie projektu Rosłońskiego do realizacji. Łącznie długość całej kanalizacji miejskiej w 1917r. wynosiła 14km.

Jednym z podstawowych czynników kształtujących standard miast jest zaopatrzenie ich mieszkańców w wodę. Wspólne działania mieszkańców Przemyśla w tym zakresie są znane od XVI w. dzięki zachowanym dokumentom. Zapewne wcześniej była to jedna lub wiele studni miejskich. Swoje studnie zapewne posiadał zamek i zgromadzenia klasztorne. Rozwijające się miasto potrzebowało oprócz wody bytowej również wody do produkcji napojów, głównie piwa, oraz produkcji rzemieślniczej $\mathrm{w}$ trakcie której zużywano wodę. Zmusiło to władze miasta do zbudowania zbiorowego systemu dostarczania wody. W 1530 r. Rada 
Miejska uchwaliła budowę wodociągu w mieście [29, s. 81]. Było to urządzenie proste technicznie i działało na zasadzie grawitacji. System składał się z drewnianych dębowych skrzyń z sitami, którymi obudowano źródliska. Ze skrzyń biegły drewniane rury do drewnianych skrzyń stanowiących zbiorniki zbiorcze, a z nich drewnianymi rurami wodę rozprowadzano do miejskich studni i sadzawek. System unowocześniano z biegiem lat i w 1584r. drewniane skrzynie zastąpiono murowanymi [29, s. 82]. Ten system nie gwarantował należytego zaopatrzenia w wodę rozrastającego się od końca XVIII w. organizmu miejskiego, zwłaszcza gdy zaczęto budować twierdzę. Władze wojskowe wybudowały dwa własne wodociągi jeden w części południowej miasta. Opierał się o system pola drenażowego na północnym stoku Tatarskiej Góry, z którego system drenów zbierał wodę stokową.

Następnie grawitacyjnie była ona przesyłana do odmulaczy i zbiornika ciśnieniowego. Po odmuleniu i wstępnej filtracji grawitacyjnie przesyłana była do zbiornika w szpitalu wojskowym przy ul. Słowackiego, skąd rozsyłana była do kompleksów koszarowych w mieście. Odmulacze i filtry pełniły jednocześnie funkcję wieży ciśnień. Do przesyłu używano ołowianych rur. Cały ten system działał do lat $90 \mathrm{XX} \mathrm{w}$. potem urządzenia zostały rozebrane. W części północnej miasta na Zasaniu w latach 90 XIX w. wojsko zbudowało wodociąg [30], który korzystał ze źródlisk ujętych $\mathrm{w}$ betonowe ocembrowania na zachodnim stoku Winnej Góry, skąd woda systemem ołowianych rur przesyłana była do odmulaczy i filtrów. Rury biegły z źródlisk akweduktem nad ciekiem wodnym i ziemnym nasypem z przepustem do odmulaczy i zbiorników retencyjnych. Wykorzystując różnice poziomów, grawitacyjnie z odmulaczy i zbiorników retencyjnych, wodę rozsyłano do kompleksów koszarowych [31].

W tym czasie działający również miejski system zaopatrzenia w wodę był niewystarczający dla powstających kamienic czynszowych i zakładów pracy. Rozwiązywano ten problem poprzez budowę indywidualnych wodociągów złożonych ze studni, pomp (napędzanych silnikami elektrycznymi w domach, a parowymi w zakładach pracy) zbiorników ciśnieniowych na strychach kamienic i sieci instalacji rozprowadzającej wodę do punktów poboru [15, s. 12]. Uzyskiwana w ten sposób woda często była zanieczyszczona i nie gwarantowała norm sanitarnych.

Miasto przystąpiło do prac mających na celu zbudowanie centralnego wodociągu dostarczającego zdrową wodę. Pierwsze próbne odwierty studzien rurowych dokonano w 1893 r. w Prałkowcach nad Sanem powyżej granic miasta. Zbudowano 12 studni próbnych, które usytuowano w trzech rzędach co 200-300 m. Studnie te były wykonane na podstawie badań B. Salbacha według projektu inżynierów Rumpela i Niklasa [29, s. 84].

Próbny rozruch nastąpił w 1895 r., wodę poddano wszechstronnym badaniom. Wypadły one korzystnie i inżynierowie sporządzili szczegółowe plany budowy wodociągu, lecz z powodu braku funduszy tego projektu nie zrealizowano. 
Dopiero gdy w 1913 r. powołano Miejskie Biuro Wodociągowe i powierzono zaprojektowanie wodociągu oraz kierownictwo robót dr. inż. Romualdowi K. Rosłońskiemu [29, s. 84], rozpoczęto realizację tej kluczowej dla miasta inwestycji.

Ostatecznie system wodociągu składał się z ujęcia wody w postaci 13 studni oraz stacji pomp, filtrów, zbiornika szczytowego i sieci wodociągowej [29]. Stację pomp oraz zbiornik wraz z filtrami zbudowano w Prałkowcach. Wzniesiono kompleks trzech budynków. W najbardziej okazałym mieści się zbiornik na wodę wraz z filtrami, obok stoi hala maszyn oraz budynek mieszkalny dla załogi. Obiekt, w którym mieści się zbiornik i filtry jest obecnie nieczynny i ma być rozebrany. Reprezentuje on ciekawy przykład architektury przemysłowej, dlatego warto przytoczyć jego opis. Budynek posadowiony jest na fundamencie $\mathrm{z}$ betonu na rzucie prostokąta. Naroża $\mathrm{w}$ formie skarp przechodzą na elewacjach w szerokie lizeny. W części centralnej elewacji wschodniej, w wysokim na jedną kondygnację cokole, znajduje się portal z półokrągłym łukiem, we wnętrzu którego umieszczono prostokątne dwunastopolowe okno. Po obu stronach portalu znajdują się nisze o półokrągłym zakończeniu. Powyżej cokołu występują na pierwszej kondygnacji cztery symetrycznie rozmieszczone okna w wnękach. Środkowe dwa okna pasmowe są sześciokwaterowe i opierają się na gzymsie cokołu, natomiast dwa boczne okna ośmiokwaterowe podkreślone są parapetami podokiennymi. Po bokach znajdują się szerokie lizeny z wnękami wyłożonymi cegłą bez tynku. Lizeny te kończą się na drugiej kondygnacji nachylonym parapetem, na którym opierają się kroksztyny okapu dachu. Okna drugiej kondygnacji o formach prostokątnych, leżą w osiach pierwszej kondygnacji, z tym, że dwa środkowe są pięciokwaterowe, po bokach znajdują się dwa dziesięciokwaterowe. Okna we wnękach podkreśla parapet. Zabytkowy obiekt pokrywa łamany dach oparty na podporach i uniesiony na ścianie skrzynkowej. W ścianie skrzynkowej znajdują się symetrycznie położone dwa czteropolowe świetliki. Dach jest czterospadowy z kalenicą o przebiegu ze wschodu na zachód i pokryty jest blachą ocynkowaną płaską. Dach oparty jest na ozdobnych wspornikach po trzy na narożach w płaszczyznach lizen i dwa proste wsporniki w środku elewacji wschodniej i zachodniej. Natomiast w elewacjach północnej i południowej znajdują się po trzy ozdobne wsporniki w lizenach narożnych oraz po dwa w lizenach naściennych i po jednym prostym między lizenami. Pozostałe elewacje rozplanowane są podobnie. Elewacja południowa szersza od wschodniej posiada oprócz narożnych skarp dwie lizeny o kształcie podobnym do lizen narożnych. Na elewacji cokołu między lizenami znajdują się półokrągłe trzy nisze. Powyżej gzymsu cokołowego na pierwszej kondygnacji, w trzech rozdzielonych lizenami wnękach, umieszczone są ośmiokwaterowe okna. Po dwa we wnęce zakończonej wspólnym parapetem. Druga kondygnacja jest analogiczna i kończy się okapem dachu na wspornikach, powyżej którego znajduje się ściana skrzynkowa zakończona dachem czterospadowym. 
W ścianie skrzynkowej znajdują się trzy czterokwaterowe świetliki. Elewacja zachodnia jest taka sama jak wschodnia z tym, że w części cokołowej nie ma okna. Elewacja północna nawiązuje do południowej z tą różnicą, że z lewej strony w skarpie cokołu znajduje się wejście, do którego prowadzą żelbetowe schody ze stalową poręczą zakończone podestem. Na pierwszej kondygnacji powyżej cokołu na ceglanych pasach narożnych lizen owalne wnęki. Między lizenami występują po jednym oknie, a w części centralnej jest tylko wnęka bez okna. W drugiej kondygnacji występują tylko okna po bokach między lizenami, w części centralnej jest gładka ściana. Elewacja zakończona jest krawędzią dachu powyżej którego jest ściana skrzynkowa z trzema czteropolowymi świetlikami i dachem głównym.

Wybudowanie stacji wodociągowej w Prałkowcach (rys. 5) dało początek budowy nowej dzielnicy Przemyśla - Prałkowce. Obok stacji wodociągowej zaczęto budować domy jednorodzinne. Następnie pod koniec XX wieku wybudowano nowy kompleks stacji uzdatniania wody oraz osiedle domów wielorodzinnych. Nastąpił kolejny przestrzenny rozwój miasta.
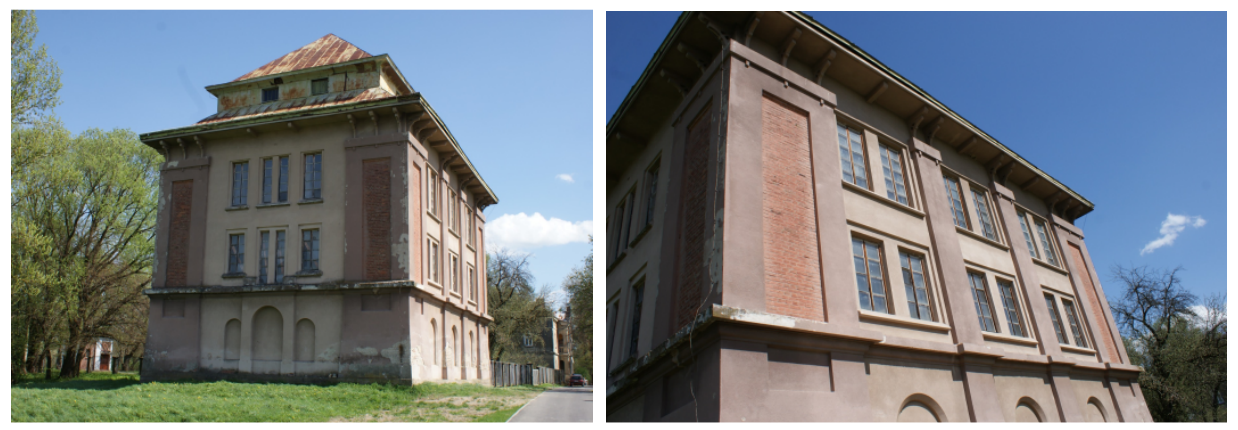

Rys. 5. Budynek wodociągów miejskich w Prałkowcach, fot. B. Motyl

Fig. 5. Building of municipal water supply systems in Prałkowce, photo. M. Motyl

\section{Perspektywiczne plany komunikacji miejskiej}

Warto tu wspomnieć o przedsięwzięciu, które nie doczekało się realizacji z powodu wybuchu wojny w 1914 r., a mianowicie o planowanym uruchomieniu linii tramwajowych. Rozrastające się przestrzennie miasto aby sprostać swoim funkcjom potrzebowało wydajnego środka transportu zbiorowego. Powstały więc dwa projekty budowy linii tramwajowych. Pierwszy, który zakładał budowę dwóch linii tramwajowych, jednej łączącej dworzec Bakończyce przez ul. Dworskiego z wybrzeżem Cesarza Franciszka Józefa (dzisiejsza J. Piłsudskiego) i ulicą Sanocką o długości $5967 \mathrm{~m}$ oraz drugiej biegnącej ulicą Słowackiego, przez Plac na Bramie, ul. Franciszkańską, ul. Kazimierza, Rynkiem, ul. Kościuszki, przez most ul. 3-go maja do boiska Sokoła, o długości 3007 m. [32, s. 8] Drugi projekt opracowany w 1912 r. przez dr. inż. Jana Stud- 
niarskiego był bardziej rozbudowany i były w nim zaprojektowane cztery trasy. Trasy te miały następujący przebieg: trasa 1-ul. 3-go maja, przez most na Sanie, ul. Kościuszki, Rynek Główny, ul. Kazimierza, ul. Franciszkańska, Plac na Bramie, ul. Mickiewicza, most przez tor kolejowy, ul. Lwowska, trasa 2 - ul. Sanocka, Wybrzeże Cesarza Franciszka, ul. Jagiellońska, Plac na Bramie, ul. Słowackiego, trasa 3 - Plac na Bramie, ul. Dworskiego, Dworzec Bakończyce, trasa 4 - ul. 3-go maja, ul. Grunwaldzka, ul. Węgierska. Oprócz torowisk i sieci trakcyjnej przewidywano budowę remiz na wozy tramwajowe. [33, s. 2] Planowano, że będzie na każdej linii po cztery wozy kursujące, co $7 \mathrm{i} 1 \frac{1}{2}$ min z szybkością $12 \mathrm{~km} / \mathrm{h}$, a w rezerwie miały być dwa wozy. [33, s. 8] Wybuch wojny niestety pokrzyżował te ambitne plany rajców miejskich, a miasto musiało w 1918 r. dokończyć przerwane wybuchem wojny inwestycje, a więc budowę wodociągów i modernizację elektrowni.

Omówione zamierzenia inwestycyjne miasta Przemyśla do 1918r, które z perspektywy minionych lat stały się jego kluczowymi zabytkami techniki, mogą nam uświadamiać, jak złożony jest proces rozwoju ośrodków miejskich i jak zależy to od wielu czynników, które nadal wpływają na rozwój tego miasta. Miasta wyjątkowego z uwagi na złożoną, wielokulturową, bogatą historię, ale również poprzez wyjątkową strukturę tkanki miejskiej, która zawiera elementy mieszkalnictwa, budownictwa przemysłowego i budownictwa wojskowego. Te komponenty zabudowy miejskiej występują oczywiście i w innych miastach, ale tylko w Przemyślu są ze sobą tak nierozerwalnie połączone, że nie tworzą osobnych dzielnic.

\section{Literatura}

[1] Hauser L.: Monografia Miasta Przemyśla, Południowo - Wschodni Instytut Naukowy w Przemyślu, Przemyśl 1991 r.

[2] Uchwała Planu Regulacji Miasta Przemyśla z 23 XII 1891 r. w zbiorach Archiwum Państwowego w Przemyślu (dalej AP w P) sygn. 1713 w zbiorze AP w P.

[3] Dalecki M.: Przemyśl w latach 1867-1914. Przestrzeń, ludność, gospodarka, praca magisterska pod kierunkiem doc. dr hab. M. Nietykszy, Uniwersytet Warszawski Instytut Historyczny, Warszawa 1988/1989 r.

[4] Girtler K.: Przemyśl w zaraniu doby autonomicznej, Południowo - Wschodni Instytut Naukowy w Przemyślu, Przemyśl 1999 r., przedruk rękopisu z 1871r.

[5] Arłamowski K.: Rozwój przestrzenny Przemyśla, Rocznik Dziejów Społecznych i Gospodarczych, T.15, PWN, Poznań 1955 r.

[6] Zając I.: Karta Biała sygn. A-417 z 1983 r., w zbiorach Wojewódzkiego Urzędu Ochrony Zabytków z siedzibą w Przemyślu (dalej WUOZ w P).

[7] Bieńkowska Z.: Karta biała sygn. A-575 z 1983 r. w zbiorach WUOZ w P.

[8] Zając I.: Karta biała sygn. A-129 z 1986 r., w zbiorach WUOZ w P.

[9] Gazeta Przemyska z 17 kwietnia 1892 r., nr 31. 
[10] Plan regulacji ulicy Słowackiego i drogi na Zielonkę sygn. 1729 AMP w zbiorach AP w P.

[11] Tramwaj Elektryczny sygn. $2160 \mathrm{w}$ zbiorach AP w P.

[12] Kieferling K.: Karta biała sygn. A-533 z 1983 r. w zbiorach WUOZ w P.

[13] Bieńkowska Z.: Karta biała sygn. brak z 2009 r., w zbiorach WUOZ w P.

[14] Zając I.: Karta biała sygn. A-88 z 1986 r., w zbiorach WUOZ w P.

[15] Rosłoński R. K.: Projekt Kanalizacji Królewskiego Miasta Przemyśla, nakładem Gminy Miasta Przemyśl, Przemyśl 1917r.,w zbiorach AP w P, sygn. 1729.

[16] Zabytki architektury przemysłowej Przemyśla [w:] Archeologia Przemysłowa w Polsce, t. 3., wyd. Fundacja Otwartego Muzeum Techniki, Wrocław 2012.

[17] Sobala D., Mermon J., Folta L., Wilczak M., Stokłosa R.: Ekspertyza Stanu Technicznego i Koncepcja Rewitalizacji Mostu Kamiennego w Przemyślu, Rzeszów 1999 r. maszynopis w zbiorach Zarządu Dróg Miejskich w Przemyślu.

[18] Projekt dekoracji Kamiennego mostu, AMP sygn. 2156 w zbiorach AP w P.

[19] Kieferling K.: Karta biała nr A 705/709 2005 r., w zbiorach Wojewódzkiego Urzędu Ochrony Zabytków z siedzibą w Przemyślu.

[20] Gazeta Przemyska z 6 sierpnia 1893 r. nr 63, sprawozdanie z posiedzenia Rady Miasta Przemyśla.

[21] Gazeta Przemyska z 25 lutego1892 r. nr 16.

[22] Marzyński S.: Podstawy projektowania architektury, Arkady, Warszawa 1969 r.

[23] Łagoda M., Wrzesiński A., Olaszek P.: Ekspertyza dotycząca wiaduktu w ciągu ulicy Zana w Przemyślu, Warszawa 1990 r., maszynopis w zbiorach Zarządu Dróg Miejskich w Przemyślu.

[24] Sobala D., Czernik K., Siwowski T.: Ekspertyza Techniczna - Most Drogowy im. Orląt Przemyskich przez rzekę San w Przemyślu, Rzeszów 2002 r., maszynopis w zbiorach Zarządu Dróg Miejskich w Przemyślu.

[25] Towarzystwo Przyjaciół Przemyśla i Regionu nr. Zesp. 1677, sygn. 2, fot. 1 - 2.

[26] Most na Sanie. Zbiór pocztówek w zbiorach AP w P, sygn. ZP/I/280.

[27] Dalecki M.: Początki Przemyskiej Energetyki 1895-1918, Rocznik Historyczno-Archiwalny XVIII, Archiwum Państwowe w Przemyślu, Przemyśl 2004r.

[28] Raport finansowy elektrowni z 1918 r., Akta Miasta Przemyśla sygn. 2220 w zbiorach A P w P.

[29] Rak J. R., Nodżak M.: Historia wodociągów przemyskich, Zeszyty Naukowe Politechniki Rzeszowskiej, Budownictwo i Inżynieria Środowiska, z. 51, Rzeszów 2009.

[30] Idzikowski T.: Zespół Zbiorników Wodociągu Zasanie, 2008r., Karta Biała w zbiorach WUOZ w P.

[31] Motyl B.: Wodociągi Wojskowe w Twierdzy Przemyśl - referat.

[32] Projekt Tramwaju Elektrycznego w Przemyślu, Akta Miasta Przemyśla sygn. 2160 w zbiorach A P w P.

[33] Opracowanie Kolei Elektrycznej dla Przemyśla, Akta Miasta Przemyśla sygn. 2159 w zbiorach A P w P. 
TECHNICAL MONUMENTS OF PRZEMYŚL DURING TURN OF THE TWENTIETH CENTURY

\section{S u m m a r y}

In the second half of the nineteenth and at the beginning of the twentieth century the spatial development of Przemyśl was significantly influenced by three main factors: the construction of fortifications around the fortress of Przemyśl and the accompanying system of barracks and logistic facilities of the fortress within the city, the construction of the railway line linking Przemyśl with Cracow, Vienna and Lviv in 1859 as well as the construction of the railway line connecting Przemyśl through the Łupkowska pass with Hungary in 1872.

The third factor was the adoption of Przemyśl streets regulations $\left(23^{\text {rd }}\right.$ December 1891) which concerned almost the entire city. It was a Europe-wide tendency connected with the period called the second Industrial Revolution.

In Przemyśl a new road and train transport system was developed. Moreover, modern for the contemporary standards marketplaces were built alongside with viaducts, technical infrastructure such as the station and a water supply system, a power station and sewer systems.

The engineering structures built at that time were used until the end of the twentieth century. After modernization and conservation works the architectural road investments have been included into modern urban functions and have been the witnesses of spatial development.

The historical infrastructure is an added value of cultural urban organism.

Keywords: cultural heritage, engineering buildings, old town, the city regulations, architectural detail

DOI:10.7862/rb.2016.154

Przestano do redakcji: 01.05.2016 r.

Przyjęto do druku: 28.06.2016 r. 